\title{
PELATIHAN MERANCANG UJIAN ONLINE MENGGUNAKAN GOOGLE FORM UNTUK GURU-GURU DI WILAYAH KECAMATAN PAMPANGAN KABUPATEN OGAN KOMERING ILIR
}

\author{
Novi Rustiana Dewi , Eka Susanti, Dian Cahyawati, Bambang Suprihatin, Herlina Hanum \\ Jurusan Matematika, Fakultas MIPA, Universitas Sriwijaya \\ Email: novirustiana@unsri.ac.id
}

\begin{abstract}
During the pandemic, teaching and learning activities in Indonesia were carried out online. Apart from online learning activities, the learning evaluation process is also carried out online. Computer applications can be used as a tool to carry out learning evaluation activities. In this service, training is given to make online exams using google form. The training participants were 32 teachers with undergraduate educational backgrounds consist of elementary, junior high school, senior high school public and private school teachers in Pampangan Subdistrict, Ogan Komering district, South Sumatra. The training activities are carried out for one day. The activity stages consist of the preparation, implementation and evaluation stages. Based on the results at the implementation and evaluation stages, it can be concluded that participants in online exam preparation training activities can make online exams using google form.
\end{abstract}

Keywords: Examinations, Google Form, Online

\begin{abstract}
ABSTRAK
Selama masa pandemi kegiatan belajar mengajar di Indonesia dilakukan secara online atau dalam jaringan. Selain kegiatan pembelajaran online, proses evaluasi pembelajaran juga dilakukan secara online. Aplikasi komputer dapat digunakan sebagai alat bantu untuk melaksanakan kegiatan evaluasi pembelajaran. Dalam kegiatan pengabdian ini diberikan pelatihan membuat ujian online dengan menggunakan google form. Peserta pelatihan sebanyak 32 orang guru dengan latar belakang pendidikan sarjana yang terdiri dari guru sekolah dasar, sekolah menengah pertama dan sekolah menengah atas negeri dan swasta di Kecamatan Pampangan, Kabupaten Ogan Komering llir, Sumatera Selatan. Kegiatan pelatihan dilaksanakan selama satu hari. Tahapan kegiatan terdiri dari tahap persiapan, pelaksanaan dan evaluasi. Berdasarkan hasil pada tahap pelaksanaan dan evaluasi dapat disimpulkan bahwa peserta kegiatan pelatihan penyusunan ujian online dapat membuat ujian online menggunakan google form.
\end{abstract}

Kata kunci: Ujian, Google Form, Online 


\section{PENDAHULUAN}

Kegiatan belajar jarak jauh pada musim pandemi saat ini menuntut para guru untuk lebih mempersiapkan materi pembelajaran dan metode evaluasi. Tujuannya adalah untuk menciptakan suasana belajar yang menarik dan tercapainya tujuan pembelajaran. Sistem pembelajaran jarak jauh (PJJ) yang diterapkan di sekolah dasar dan sekolah menengah yang berada di wilayah kecamatan Pampangan adalah menggunakan aplikasi Whatsapp (WA). Komunikasi antara guru dan siswa melalui grup WA untuk setiap mata pelajaran. Guru memberikan materi pembelajaran dan penugasan kepada siswa setiap harinya melalui WA. Tugas yang diberikan berupa instruksi untuk merangkum bagian pelajaran tertentu dan menyelesaikan soa-soal latihan. Jawaban soal dikirim melalui WA.

Berdasarkan diskusi dengan pihak sekolah, salah satu permasalahan dalam penerapan PJJ adalah belum adanya variasi penggunaan media evaluasi pembelajaran secara online. Akibatnya alat evaluasi dan penilaian kepada siswa belum optimal. Terdapat kesulitan dalam mengevaluasi kemampuan siswa dalam suatu mata pelajaran secara individu. Penggunaan google form untuk melakukan ujian secara online diharapkan dapat memberikan penilaian secara tepat untuk setiap individu siswa.

Kajian terkait pembelajaran jarak jauh (PJJ) dilakukan oleh (Eryadini et al., 2020) mengkaji psikologi belajar jarak jauh pada masa pandemi. (Anugrahana, 2020) membahas mengenai hambatan, solusi dan harapan pada pembelajaran daring di sekolah dasar. Metode dan media evaluasi pada pembelajaran daring juga diperlukan untuk tercapainya tujuan pembelajaran. Kajian mengenai evaluasi pembelajaran secara daring telah banyak dilakukan. (Pratama \& Yusro, 2016) memperkenalkan Whatsapp Mobile Learning sebagai upaya meningkatkan hasil belajar pada pokok bahasan Konsep Dasar Elektronika. (Rahmanto \& Soyusiawaty, 2015) memperkenalkan sistem informasi ujian mandiri online berbasis web. (Susilowati \& Hidayat, 2018) memberikan rancang bangun sistem informasi ujian online berbasis web. (Pratiwi et al., 2015) menggunakan metode pembelajaran Quiz teams. (Saraswati \& Putra, 2015) juga melakukan penelitian mengenai ujian online berbasis website. (Satria \& Wati, 2016) memperkenalkan ujian online berbasis client server. (Nurhayati \& Lestari, 2020) memperkenalkan pembelajaran berbasis Whatsapp dan flash game player. (Putra et al., 2019) melakukan evaluasi Ujian Online dengan Menggunakan Learning Management System Moodle Berbasis Android di SMK Negeri 1 Jakarta.

Dari beberapa pembahasan terkait PJJ dan analisis situasi terhadap pihak sekolah dapat disimpulkan bahwa penerapan ujian online sangat mungkin dilaksanakan terlebih di masa pandemi seperti sekarang ini. Ujian online menggunakan aplikasi google form sangat mungkin untuk dapat dilaksanakan pada beberapa sekolah menengah pertama yang berada di desa Pampangan. Hal ini didasarkan pada analisa siswa memiliki telepon seluler dan Sebagian besar guru memiliki laptop. Jaringan provider internet juga tersedia cukup baik di wilayah kecamatan Pampangan. Para guru-guru di desa Pampangan juga sudah cukup mengenal teknologi komputer, akan tetapi untuk penyelenggaraan ujian online menggunakan google form belum pernah dilaksanakan selama proses pembelajaran jarak jauh saat ini. Dengan memperhatikan kondisi yang ada saat ini, maka tim pengabdian menganggap penting untuk memperkenalkan ujian online menggunakan google form.

\section{METODE PELAKSANAAN}

Kegiatan pengabdian merancang ujian online menggunakan google form dibagi dalam tiga tahap, yaitu:

\section{Tahap Persiapan}

Tahap persiapan terdiri dari persiapan tim pengabdian dan pihak sekolah sebagai mitra kegiatan.

Tahapan persiapan oleh tim pengabdian meliputi kegiatan analisis awal permasalahan kegiatan

PJJ di wilayah kecamatan Pampangan. Identifikasi masalah dilakukan dengan wawancara secara online kepada pihak sekolah. Dari tahap ini diperoleh bahwa sistem pengujian online yang 
diterapkan guru-guru SMPN 1 Pampangan belum optimal, terdapat beberapa kendala dalam proses pengujian. Persiapan selanjutnya adalah Survey awal lokasi kegiatan, perizinan lokasi, penyusunan proposal, penyusunan materi yang akan disampaikan, koordinasi dan pembagian tugas tim pengabdian. Persiapan pihak sekolah adalah menyebarluaskan undangan untuk peserta pelatihan melalui google form yang telah dipersiapkan tim pengabdian.

2. Tahap Pelaksanaan

Tahap pelaksanaan terdiri dari tahap penyampaian materi dan simulasi. Penyampaian materi dan diskusi dilakukan sebanyak satu kali pertemuan. Pertemuan secara tatap muka dilakukan dengan tetap memperhatikan protocol covid. Setelah penyampaian materi dilanjutkan dengan simulasi peserta membuat ujian online dan mempresentasikan hasil. Kegiatan diikuti oleh 32 guru sekolah dasar dan menengah yang berada di wilayah kecamatan Pampangan. Materi yang disampaikan pada kegiatan pelatihan adalah aktivasi akun google dan materi pembuatan ujian online menggunakan google form.

3. Tahap evaluasi

Tahap evaluasi dilakukan dengan memberikan kuesioner menggunakan google form kepada seluruh peserta pelatihan. Link kuesioner diberikan di akhir pelaksanaan kegiatan.

\section{HASIL DAN PEMBAHASAN}

Kegiatan pengabdian merancang ujian online untuk guru-guru di kecamatan Pampangan Kabupaten Ogan Komering llir Sumatera Selatan dilaksanakan pada bulan November 2020. Kegiatan berlokasi di SMPN 1 Pampangan. Khalayak sasaran pada kegiatan ini adalah 32 orang guru yang terdiri dari guru SD, Guru SMP/MTs, dan Guru MA yang ada di wilayah kecamatan Pampangan. Kegiatan pengabdian dilaksanakan dalam beberapa tahap yaitu, tahap persiapan, tahap pelaksanaan dan tahap evaluasi.

Pada tahap persiapan dapat diidentifikasi masalah yang ada di sekolah SMPN 1 Pampangan dalam pelaksanaan PJJ dan pengujian secara online yaitu belum bervariasinya media pembelajaran sehingga motivasi belajar siswa masih rendah. Kesulitan dalam penilaian individu kepada siswa secara online juga menjadi masalah dalam PJJ yang diterapkan. Pengenalan google form dapat menjadi solusi dalam permasalahan penilaian PJJ.

Tahapan kegiatan selanjutnya adalah pelaksanaan kegiatan. Pelaksanaan kegiatan dibagi dua yaitu penyampaian materi oleh tim pengabdian, simulasi dan presentasi hasil oleh peserta pelatihan. Kegiatan pelatihan dibuka oleh kepala sekolah SMPN 1 Pampangan. Pada kata sambutannya kepala sekolah menyampaikan ucapan terima kasih dan apresiasi kepada tim pengabdian atas pelaksanaan kegiatan pelatihan untuk guru-guru di wilayah kecamata Pampangan. Kegiatan pelatihan pembuatan ujian online menggunakan google form merupakan kegiatan pelatihan yang pertama kali dilakukan di wilayah kecamatan Pampangan dan sangat bermanfaat untuk mendukung pelaksanaan PJJ. Kata pembuka juga disampaikan oleh perwakilan dari tim pengabdian. Disampaikan ucapan terima kasih kepada pihak sekolah SMPN 1 Pampangan yang bersedia menjadi lokasi pelaksanaan kegiatan dan membantu tahapan persiapan dari kegiatan pelatihan seperti pada Gambar 1. 


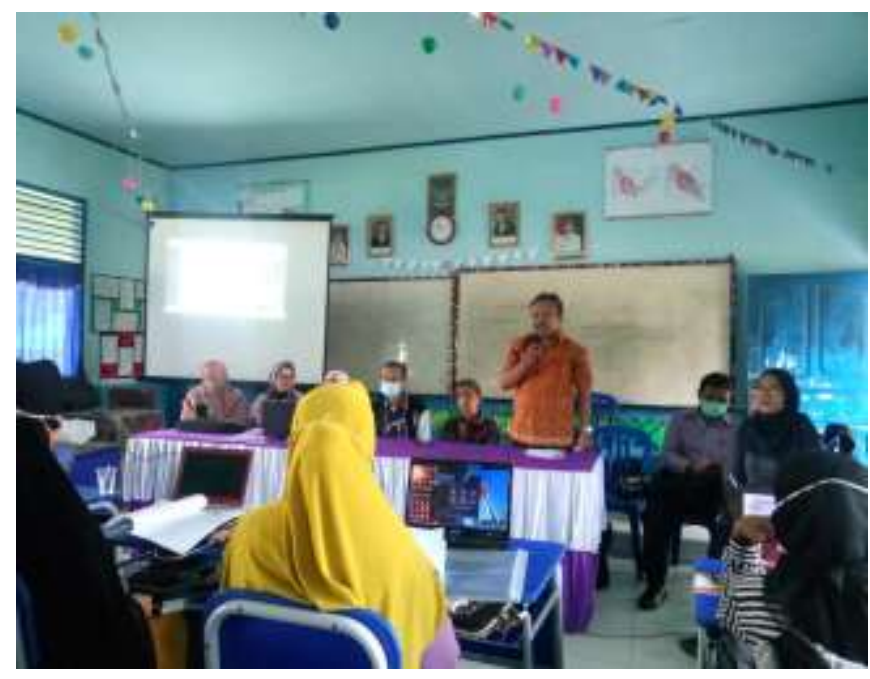

Gambar 1. Acara pembukaan kegiatan pengabdian

Beberapa peserta pelatihan belum mempunyai akun google, maka sebelum penyampaian materi dilakukan aktivasi akun google. Pada tahap ini, tim pengabdian memastikan bahwa setiap peserta memiliki akun google yang aktif. Dibantu mahasiswa, peserta berhasil membuat dan mengaktifkan akun google. Peserta mendapatkan modul penggunaan google form berupa soft copy satu hari sebelum kegiatan. Soft copy diberikan melalui grup WA. Selain soft copy, pada pelaksanaan kegiatan diberikan hard copy modul kegiatan untuk masing-masing peserta dan tim pengabdian. Peserta membawa laptop dan media untuk koneksi internet. Koneksi jaringan internet sangat baik selama pelaksanaan kegiatan.

Penyampaian materi dan simulasi pembuatan ujian online menggunakan google form disampaikan oleh ketua tim pengabdian. Penyampaian materi diberikan mengikuti tahapan pembuatan ujian online yang dijelaskan di modul kegiatan. Disampaikan materi mengenai bagaimana membuat beberapa tipe soal yaitu, tipe jawaban singkat, pilihan ganda, menambahkan foto dan video pada soal. Diberikan juga penjelasan bagaimana menambahkan kunci jawaban dan skor penilaian serta bagaimana cara membagikan link google form yang telah dibuat kepada siswa melalui Whatsapp seperti pada Gambar 2.

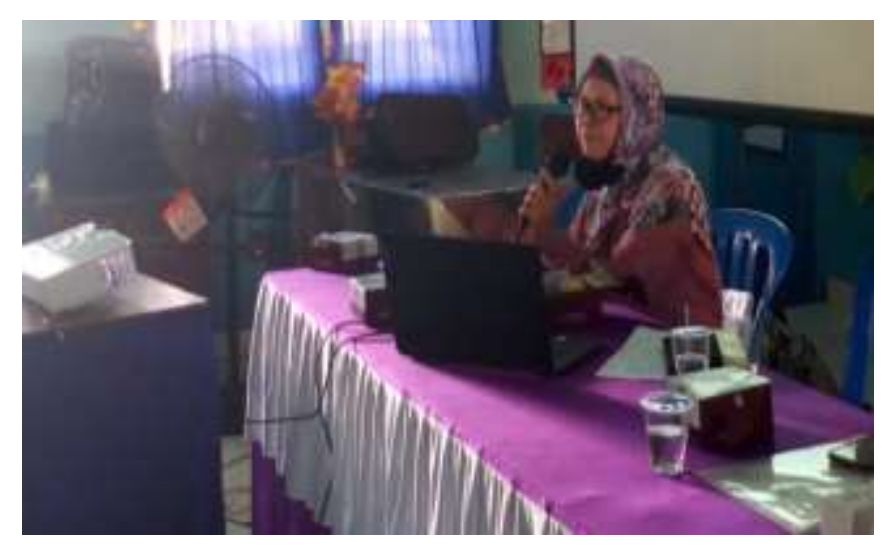

Gambar 2. Kegiatan penyampaian materi

Diskusi dan tanya jawab diberikan setelah penyampaian materi. Dari beberapa pertanyaan yang diajukan, secara umum peserta mengajukan pertanyaan terkait bagaimana cara membagikan link 
google form yang telah dibuat ke siswa dan mengarsipkan respon yang diberikan siswa. Terdapat juga pertanyaan peserta apakah telepon seluler dapat digunakan oleh siswa untuk memberikan respon terhadap google form. Diskusi berlangsung aktif, hal ini terlihat dari banyaknya pertanyaan yang diajukan. Pertanyaan peserta dijawab dengan baik oleh perwakilan tim pengabdian dan peserta merasa cukup jelas dengan penjelasan tim pengabdian. Dengan adanya diskusi dan tanya jawab diharapkan tahapan simulasi pembuatan ujian online menggunakan google form dapat berjalan dengan baik.

Tahapan pelaksanaan kegiatan selanjutnya adalah simulasi membuat ujian online menggunakan google form sesuai mata pelajaran yang diampuh oleh masing-masing peserta. Pada tahap ini, peserta didampingi oleh beberapa mahasiswa. Peserta membuat satu rancangan ujian online yang memuat tipe jawaban singkat, pilihan ganda yang disertai dengan tambahan video atau gambar. Kegiatan simulasi berlangsung selama kurang lebih 40 menit seperti terlihat pada Gambar 3.

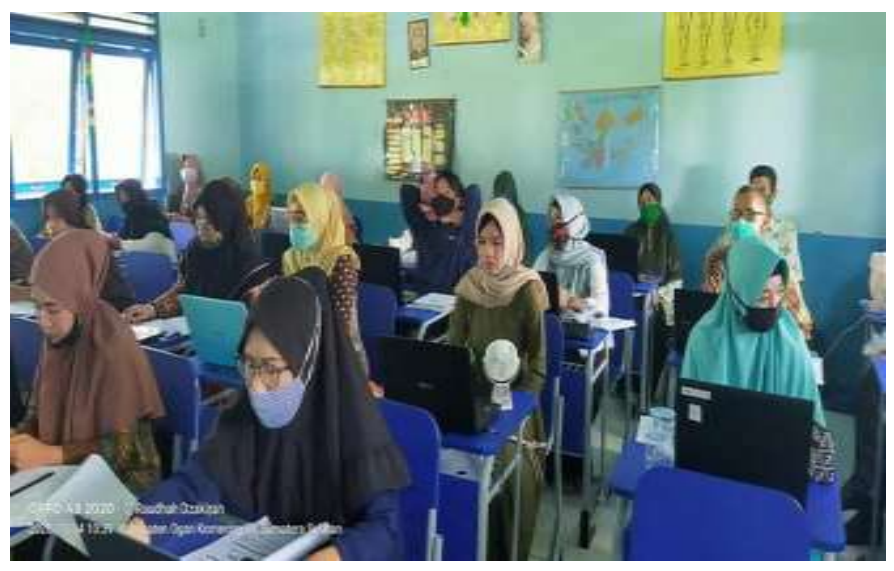

Gambar 3. Kegiatan simulasi membuat Ujian Online

Tiga orang peserta diminta untuk mempresentasikan rancangan ujian online yang telah dibuat. Ketiga peserta tersebut terdiri dari guru pengampuh mata pelajaran IPA, Matematika dan IPS. Pada tahapan ini juga dilakukan simulasi membagikan link google form ke peserta pelatihan lainnya. Peserta lain mencoba memberi respon pada google form dari peserta yang sedang presentasi seperti terlihat pada Gambar 4.

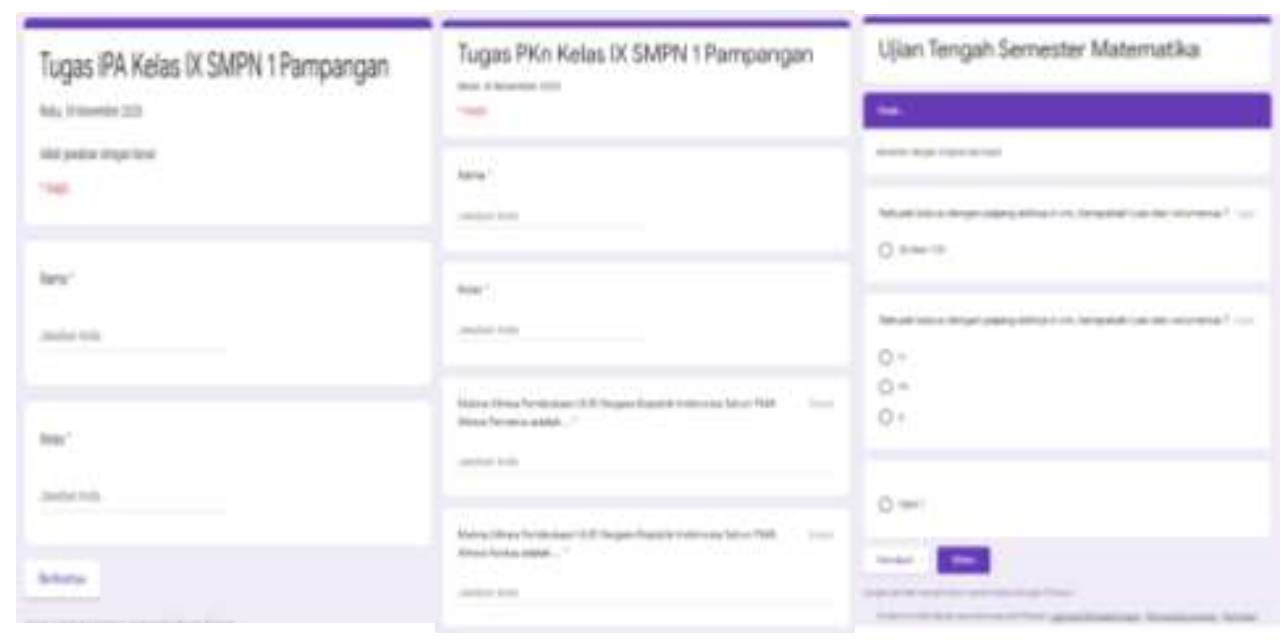

Gambar 4. Tampilan Google Form Peserta 
Sebagai penutup pelaksanaan kegiatan pengabdian di SMPN 1 Pampangan, diberikan cendera mata kepada pihak sekolah. Kegiatan ditutup oleh bapak kepala sekolah SMPN 1 Pampangan. Dalam kata penutup, kepala sekolah mengharapkan kegiatan pelatihan terkait pengenalan teknologi dalam mendukung proses pembelajaran diadakan secara berkelanjutan dalam rangka memberi wawasan dan tambahan ilmu kepada guru-guru yang ada di wilayah kecamatan Pampangan. Sebagai masukan untuk tim pengabdian, diberikan kuesioner evaluasi pelaksanaan kegiatan. Kuesioner peserta diberikan dalam bentuk google form dan diberikan setelah kegiatan penutupan. Deskripsi respon kuesioner peserta diberikan pada Tabel 1.

Tabel 1. Tanggapan Kuesioner Evaluasi Kegiatan Pengabdian

\begin{tabular}{|c|c|}
\hline Pertanyaan & Tanggapan \\
\hline $\begin{array}{l}\text { 1. Apakah Anda telah mengetahui apa itu } \\
\text { Gooogle Form sebelumnya? }\end{array}$ & $\begin{array}{l}87,5 \% \text { menjawab Belum Pernah } \\
12,5 \% \text { menjawab pernah }\end{array}$ \\
\hline $\begin{array}{l}\text { 2. Apakah Anda sudah pernah } \\
\text { menggunakan Google Form dalam } \\
\text { proses pembelajaran? }\end{array}$ & $100 \%$ menjawab Belum Pernah \\
\hline $\begin{array}{l}\text { 3. Apakah materi yang disampaikan } \\
\text { menarik? }\end{array}$ & $\begin{array}{l}37,5 \% \text { menjawab Menarik } \\
62,5 \% \text { menjawab sangat menarik }\end{array}$ \\
\hline $\begin{array}{l}\text { 4. Apakah penyampaian materi mudah } \\
\text { dimengerti? }\end{array}$ & $\begin{array}{l}37,5 \% \text { menjawab Mudah } \\
62,5 \% \text { menjawab sangat Mudah }\end{array}$ \\
\hline 5. Pesan dan kesan terhadap pelatihan ini & $\begin{array}{l}\text { Secara umum peserta menyatakan materi } \\
\text { sangat bermanfaat dan berharap kegiatan } \\
\text { dilaksanakan secara berkelanjutan }\end{array}$ \\
\hline
\end{tabular}

Sumber : Kuesioner Kegiatan Pengabdian Tanggal 14 November 2020

\section{SIMPULAN}

Kegiatan pengabdian kepada masyarakat yang diadakan dalam bentuk pelatihan dan pendampingan membuat ujian online dapat berjalan sesuai tahapan yang direncanakan. Secara umum peserta pelatihan dapat mengikuti materi yang disampaikan dan melakukan simulasi membuat ujian online. Kondisi jaringan internet di desa Pampangan sangat mendukung kelancaran kegiatan pelatihan. Berdasarkan tanggapan terhadap kuesioner dapat disimpulkan bahwa sebelum mengikuti kegiatan pelatihan peserta belum pernah menggunakan google form pada kegiatan evaluasi pembelajaran di sekolah. Kegiatan pengabdian merancang ujian online memberikan manfaat dan menambah wawasan para guru sebagai peserta kegiatan dalam mempersiapkan ujian secara online untuk masing-masing mata pelajaran yang diampuh.

\section{UCAPAN TERIMAKASIH}

Ucapan terima kasih disampaikan kepada Universitas Sriwijaya yang telah mendanai kegiatan pengabdian tahun 2020 melalui anggaran dana PNBP Sesuai dengan Surat Perjanjian Penugasan Tenaga Pelaksana Pengabdian Kepada Masyarakat Skema Aplikasi IPTEK dan Pengembangan Seni Budaya Lokal Universitas Sriwijaya Nomor.0018.165/UN9/SB3.LP2M.PM/2020,Tanggal 23 Oktober 2020. Ucapan terima kasih juga disampaikan kepada pihak sekolah SMPN 1 Pampangan sebagai tempat pelaksanaan kegiatan pengabdian. 


\section{REFERENSI}

Anugrahana, A. (2020). Hambatan, Solusi dan Harapan: Pembelajaran Daring Selama Masa Pandemi Covid-19 Oleh Guru Sekolah Dasar. Scholaria: Jurnal Pendidikan Dan Kebudayaan, 10(3), 282-289.

Eryadini, N., Nafisah, D., Sidi, A., \& Buana-lamongan, U. P. A. (2020). Psikologi Belajar Dalam Penerapan Distance Learning. Jurnal Pendidikan Dan Pengabdian Masyarakat, 3(3), 163-168.

Nurhayati, I., \& Lestari, P. (2020). Pembelajaran Berbasis Whatsapp dan Flash Game Player. Maju, 7(2), 28-43.

Pratama, H., \& Yusro, A. C. (2016). Implementasi WhatsApp Mobile Learning Untuk Meningkatkan Hasil Belajar Mahasiswa Pokok Bahasan Pengenalan Komponen Elektronika. Jurnal Pendidikan Fisika Dan Keilmuan (JPFK), 2(2), 65. https://doi.org/10.25273/ipfk.v2i2.696,

Pratiwi, W., Yamtinah, S., \& Redjeki, T. (2015). Penerapan Metode Pembelajaran Quiz Team Untuk Meningkatkan Aktivitas Dan Prestasi Belajar Siswa Pada Materi Kelarutan Dan Hasil Kali Kelarutan Di Kelas Xi Ipa 2 Sma Al Islam 1 Surakarta Tahun Ajaran 2014/2015. Jurnal Pendidikan Kimia, 5(1), 46-54.

Putra, R. L., Maulana, A., \& Iriani, T. (2019). Evaluasi Program Pelaksanaan Ujian Online Dengan Menggunakan Learning Management System Moodle Berbasis Android Di Smk Negeri 1 Jakarta. Jurnal PenSil, 8(1), 47-54. https://doi.org/10.21009/jpensil.v8i1.8483.

Rahmanto, E., \& Soyusiawaty, D. (2015). Sistem Informasi Ujian Mandiri Online Berbasis Web. Jurnal Sarjana Teknik Informatika, 3 (Februari), 80-88. http://journal.uad.ac.id/index.php/JSTIF/ article/view/2925/pdf_34.

Saraswati, N. W. S., \& Putra, D. M. D. U. (2015). Sistem Ujian Online Berbasis Website. S@Cies, 6(1), 21-30. https://doi.org/10.31598/sacies.v6i1.78.

Satria, D., \& Wati, L. (2016). Perancangan Ujian Online Menggunakan Model Computer Based AssesmentBerbasis Client-Server (Studi Kasus: SMA PGRI Kota Payakumbuh). INOVTEK Polbeng - Seri Informatika, 1(1), 57. https://doi.org/10.35314/isi.v1i1.139.

Susilowati, S., \& Hidayat, T. (2018). Rancang Bangun Sistem Informasi Ujian Online ( Studi Kasus Pada SMAN 58 Jakarta ). Jurnal Teknik Komputer, 4(1), 7. 